\title{
Contact as catalyst: The case for Coptic influence in the development of Arabic negation ${ }^{1}$
}

\author{
CHRISTOPHER LUCAS \& ELLIOTT LASH \\ University of Cambridge \\ (Received I5 May 2008; revised 9 June 2009)
}

This article discusses similar developments in the expression of negation in the histories of Egyptian-Coptic and Arabic and explores the evidence for these respective developments being related by language contact. Both Coptic and Arabic have undergone a development known as Jespersen's Cycle (JC), whereby an original negative marker is joined by some new element to form a bipartite negative construction. The original marker then becomes optional while the new element becomes the primary negator. We present the results of a corpus study of negation in late Coptic, showing that, at the time when Arabic speakers began to settle in Egypt, the bipartite negative construction still predominated. This being the case, we argue that native speakers of Coptic learning Arabic as a second language played a key role in the genesis of the Arabic bipartite negative construction. More generally, we give reasons to doubt the a priori preference for internal explanations of syntactic change over those involving contact, as well as the assumption that the two are mutually exclusive. Rather, we suggest that not only purely internal but also (partially) contactinduced change can profitably be accounted for in terms of child language acquisition leading to a change in the grammars of individual speakers.

\section{INTRODUCTION}

\section{I.I Indo-European}

The historical development of negation is a topic which has become the focus of increasing interest in recent years, particularly in studies of European languages (see, for example, Detges \& Waltereit 2002 on French,

[I] Parts of this paper were presented in Nijmegen, Milan and Leipzig in 2008. We would like to thank the two anonymous $J L$ referees, as well as David Willis and Johan van der Auwera, for their detailed and insightful comments on earlier, inferior, drafts. We would also like to thank Ariel Shisha-Halevy for the initial suggestion that the issue investigated here was worth investigating. This work was funded by a Ph.D. studentship from the Arts and Humanties Research Council and an Overseas Research Studentship award from the University of Cambridge.

Lists of abbreviations used in example glosses and example source annotations can be found in the appendix. 
Tieken-Boon van Ostade, Gunnel \& van der Wurff 1998 on English and Burridge 1993 on Dutch). A recurring feature of a range of European languages which appears first to have been discussed in detail by Jespersen (1917), ${ }^{2}$ and which has been named for him since Dahl (1979), is Jespersen's Cycle (JC). In languages which undergo JC, sentential negation at an initial stage is marked by some preverbal element, as in Old English, ic ne secge 'I do not say'. This we will call stage I. At stage II some postverbal element, often formerly a noun of minimal quantity or a word meaning '(no)thing', is grammaticalized to form a bipartite negative construction together with the original preverbal marker, as in Middle English I ne seye noht 'I do not say'. At stage III the original preverbal negative element becomes optional and is then lost altogether, so that the innovative postverbal item now suffices as the sole, unmarked negator, as in Early Modern English I say not. As a potentially cyclic process, stage III can then give way to what is arguably stage $I^{\prime}$ in English, with negation once again being expressed preverbally, albeit on an auxiliary: I don't say (Jespersen I9I7: 9-II).

One interesting feature of this development that has become clear as the data from studies of individual languages have been collated is the extent to which its distribution in the languages of Europe is clustered geographically (see figure I, Bernini \& Ramat I996).

Progression from stage I to stage II or III has occurred in Welsh (Willis 2006), English, French, Breton (Borsley, Tallerman \& Willis 2007: 3I2), Romance dialects of Switzerland and northern Italy (Parry 1997), Dutch, German (Jäger 2008), and Old Norse (Eythórsson 2002), but apparently not in other Indo-European languages spoken in Europe (including Irish, Scots Gaelic and many Romance varieties of Spain and Italy). An apparent implication of this geographical clustering is that the progression of a given language from stage I to stage II is strongly correlated with contact with another language which is itself also stage II (or conceivably stage III, but see section 3.I). It should be clear, however, that contact with a stage II language is neither a necessary nor a sufficient condition for a stage I language to develop a stage II construction. It is not necessary because at least one of the above-mentioned languages must have been the first in this area to develop (independently) a stage II construction; and it is not sufficient because neither Romance varieties spoken south of northern Italy and the Pyrenees, nor German-influenced Slavonic varieties such as Sorbian, Czech and Slovene, have developed a stage II construction, despite having been in extensive contact with languages which had one. This point is important for what follows, when we consider the situation in Egypt and North Africa.

[2] It is mentioned in passing by earlier authors, such as Gardiner (I904) and Meillet (I9I2: 393-394). 


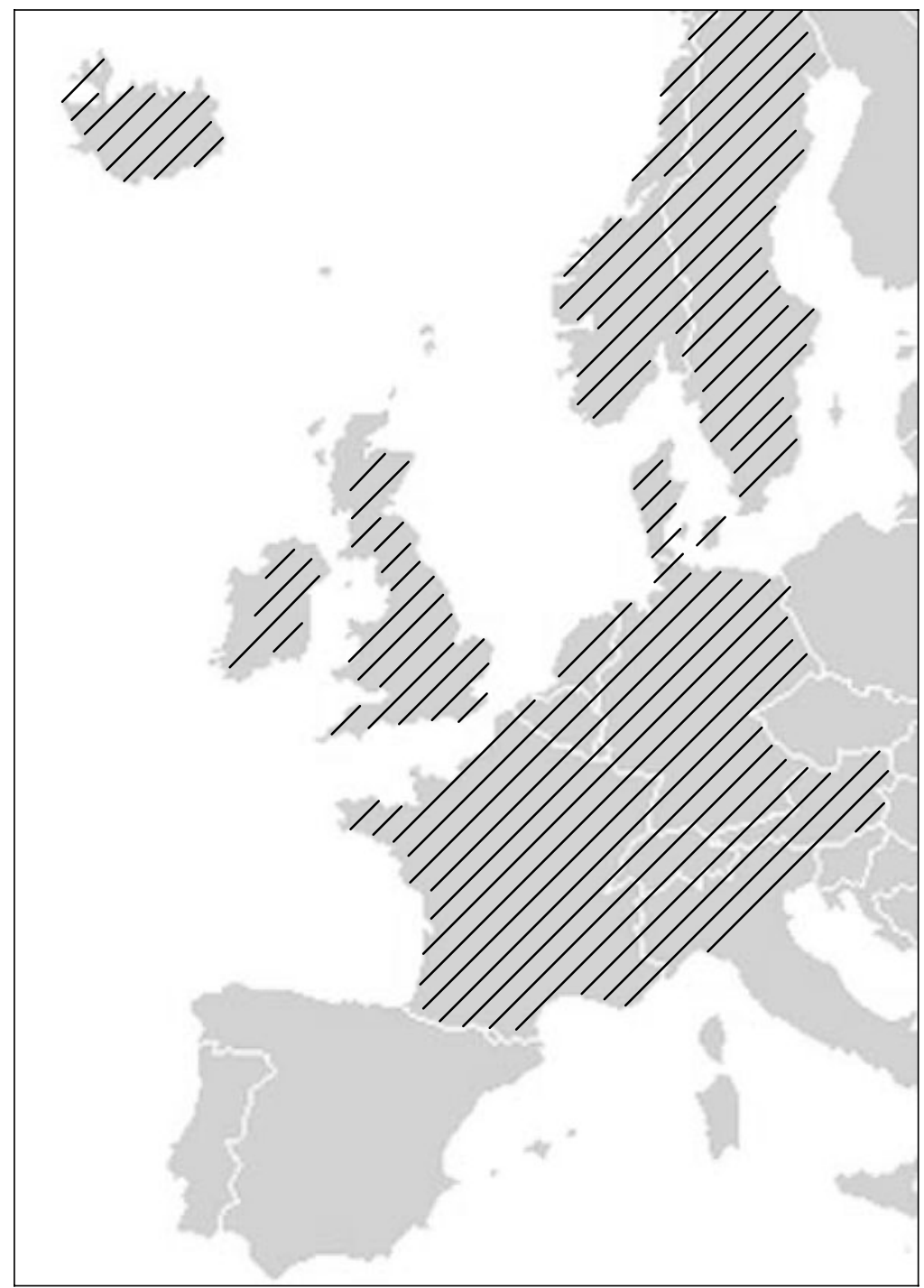

Figure I

Traditional varieties spoken in the shaded areas have all undergone JC.

\section{I.2 Afro-Asiatic}

It has not gone unnoticed that JC is also a feature of the development of various Afro-Asiatic languages. Gardiner (1904) discusses the rise of the postverbal negator an $(<i w n 3)$ in Late Egyptian, and more recently there has been work on this topic by Kickasola (1975), Meltzer (1990) and Winand (1997). JC in Arabic and Berber has been mentioned intermittently by, 
e.g. Basset (1952), Brugnatelli (1986) and Chaker (1996), but appears not to have been the subject of detailed study before Lucas (2007). In this latter paper, and in Lucas (2009), it is argued that the presence of a stage II construction in many varieties of North African Arabic and Berber is due to Berber-Arabic contact, specifically borrowing under recipient-language agentivity (in the sense of Van Coetsem 1988, 2000) by native speakers of Berber. It is further claimed that the innovation of a stage II construction in Arabic was an entirely internal development. The purpose of this article is to explore the possibility that this latter claim is wrong - that, in fact, it was contact with Coptic that was at least partially responsible for triggering JC in (Egyptian) Arabic. In so doing it is also intended to contribute to the wider debate on what counts as evidence in historical (contact) linguistics, and how contact can lead to change.

The article is structured as follows. Section 2 sets out the data and historical background of JC in Arabic dialects, drawing on Lucas (2007). In section 3.I the essentials of the Coptic negation system are presented, and the broad similarities with respect to Arabic are highlighted. The question then arises, to the extent that we find similarities, are these simply coincidental, or could they be in part due to imposition of the stage II construction by native speakers of Coptic on their second language (L2) Arabic? The first step in answering this question is to ascertain whether the stage II construction remained frequent up to and including the period of contact with Arabic, or whether, by that time, it had been ousted by the stage III construction. Section 3.2 presents the results of a corpus study of ninth- and tenth-century Coptic texts, which show that, while there are examples of stage III constructions in all of these texts, in the relevant domains Coptic remained predominately stage II up to this time. On this basis, the hypothesis of Coptic influence on the development of the Arabic stage II construction is discussed in more detail in section 4, and in section 5 a model is sketched of the acquisitional processes which might underlie this kind of contact-induced change, drawing on the work of Van Coetsem $(1988,2000)$.

\section{Arabic sentential negation}

Classical Arabic had a variety of preverbal sentential negators, the oldest of which would appear to be $l \bar{a}$ (compare Biblical Hebrew lo), this being largely restricted to the negation of imperfect verb-forms:
(I) Pak日aru-hum lā yaSlamūna most.NOM-of.them NEG know.IMPF.3MPL 'Most of them do not know.'

In addition to this we find a negator exclusively for the past (lam) and one exclusively for the future (lan), as well as a negative copula laysa, and a rarely 
used general-purpose negator Pin. Much more common was $m \bar{a}$, which could be used with all tenses:

(2) wa

wa-mā zalamū-nā $\quad$ wa-lākin kānū
and-NEG wrong.PRF.3MPL-us and-but be.PRF.3MPL
yazlimūna
wrong.IMPF.3MPL
'And they did not wrong us but they wronged themselves.'

(Qur'ān 2: 57)

$m \bar{a}$ as negator appears to be an innovation within the prehistory of Arabic (for a different view see Faber I99I). It seems to be derived from a homophonous item $m \bar{a}$, an interrogative pronoun with cognates in other Semitic languages (e.g. Hebrew $m a$ ). The negators other than $m \bar{a}$ are becoming obsolete in the modern spoken Arabic dialects. Those dialects which have remained at stage I of JC retain the Classical negative construction with preverbal $m \bar{a}$ :

(3) Pal-lon mā-ḥabbēt-ha

say.PRF.3MSG-to.them NEG-love.PRF.ISG-her

'He told them, "I didn't fall in love with her'.'

(Syrian Arabic - Brustad 2000: 284)

A stage II construction is found in the Arabic dialects spoken across coastal North Africa including on Malta, in and around Palestine, and in parts of Yemen and Oman (Lucas 2007). All other dialects appear to have remained at stage I (see figure 2). The Arabic stage II construction is composed of this same preverbal element $m \bar{a}$ (sometimes with a reduced vowel), together with a postverbal enclitic ultimately derived from the Classical Arabic word $\check{s} a y$ ? 'thing' and consisting essentially of the phoneme $/ \mathrm{f} /$, sometimes appearing as a fuller form $-s ̌ \bar{l}$ or $-s \bar{s} \bar{e}$, or with a preceding epenthetic vowel:

(4) ma-bəhịbb- ${ }^{\mathrm{i}} \mathrm{s} \quad$ migiyy-u hina ktīr

NEG-like.IMPF.ISG-NEG coming-his here much

'I don't like his coming here a lot.'

(Egyptian Arabic - Woidich I968: 33)

Some dialects, spoken in (for example) Palestine and the south of the Arabian Peninsula, exhibit stage III constructions in restricted contexts, for example with imperfect but not perfect verb-forms in Palestinian:

$$
\begin{aligned}
& \text { ana bašrab-š } \quad \text { il-Pahwa } \\
& \text { I drink.IMPF.ISG-NEG the-coffee } \\
& \text { 'I don't drink coffee.' }
\end{aligned}
$$

Despite this, it would probably be a mistake to see $-\check{s}$ and not $m \bar{a}$ as the 'true' negator in Arabic stage II varieties, analogously to French pas versus ne. For one thing, in every Arabic variety that features a stage II construction, 


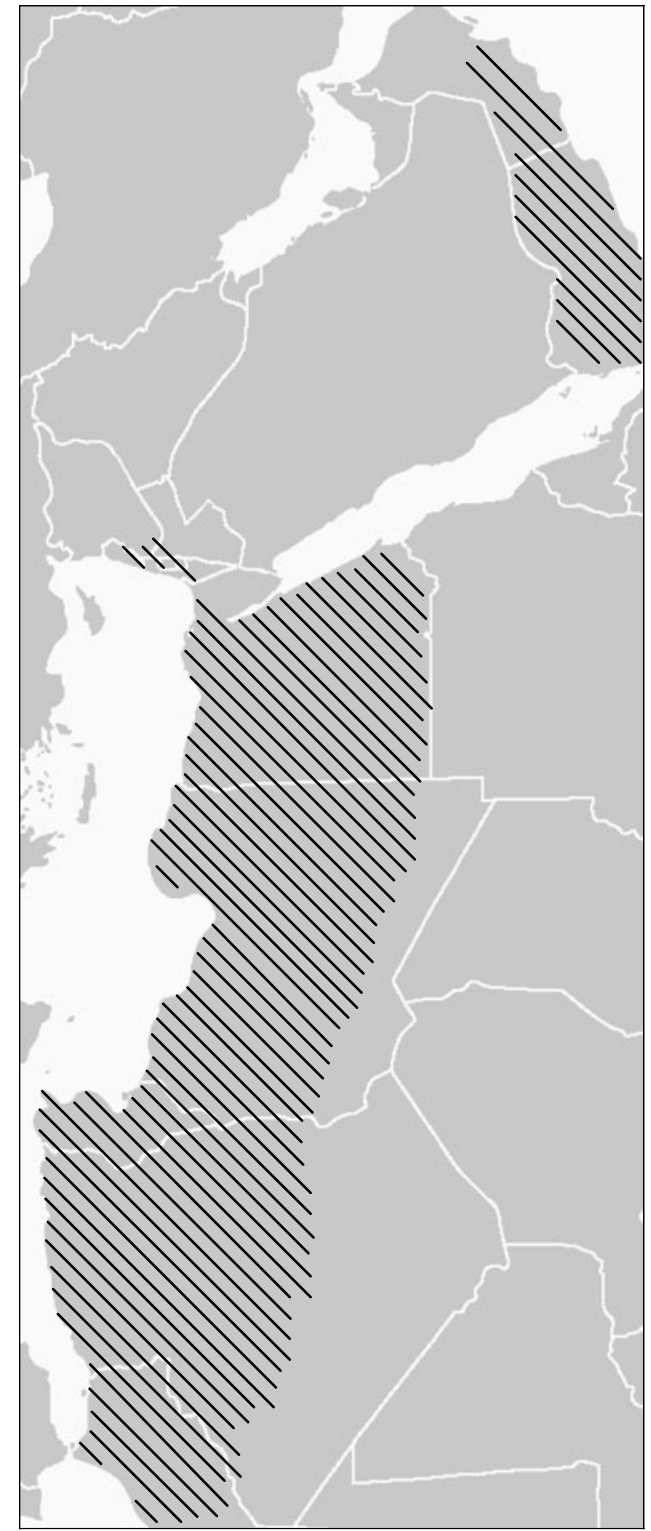

Figure 2

Shaded areas indicate regions in which a stage II/III Arabic variety is currently spoken. All other regions stage I or non-Arabic-speaking.

including Palestinian, there are frequently occurring contexts in which a stage I construction with $m \bar{a}$ alone is the norm, for example, sentences introduced by wallāhi 'by God'. Thus, either $m \bar{a}$ or $-\check{s}$ alone are able to identify 
negation, whereas the two together do not result in a double negative, that is, affirmative, interpretation. As such, it seems preferable in cases such as these to see semantic negation as a property, not of individual lexical items, but of the whole proposition expressed by a sentence. ${ }^{3}$

Tracking the historical development of any linguistic change in the spoken Arabic dialects through textual evidence is problematic due to the near-total dominance of a highly conservative form of Classical Arabic in written texts in the pre-modern period. Only a small number of these have any significant degree of colloquial influence, and this rarely seems to manifest itself in the domain of negation, perhaps because the differences between the Classical negation system and that of the stage II dialects are salient enough for all but the most careless authors to adhere to the Classical norm.

Nevertheless, a comparison of the present-day situation in the various dialects taken together with what we know about the spread of Arabic in the early days of Islam can give us a broad-brush picture of the geography and chronology of JC in spoken Arabic.

Lucas (2007) shows that the stage II construction in Arabic arose in North Africa east of Morocco between the eighth and eleventh centuries. This conclusion is based on data from isolated and outlying varieties of Arabic whose speakers are known to have become cut off from speakers of more mainstream varieties of Arabic at a certain period in their development. Accordingly, where these isolated varieties today share features with more mainstream varieties, we can reasonably conclude that these features were present in the ancestors of each of these varieties at a time when they were still in contact.

First of all, evidence from present-day Cypriot Maronite Arabic (CMA), an endangered language spoken by a small number of Maronite Christians in northern Cyprus, corroborates the uncontroversial assumption that the spoken Arabic of pre-Izoo Arabia and the Levant was still stage I. Cyprus was ruled jointly by the Arabs and the Byzantine Empire between the seventh and tenth centuries and thereafter by the Byzantines alone. There continued to be extensive contact with Arabic speakers, however, as this period saw a steady influx of Maronite Christians from the Levant, though

[3] In Minimalist terms this could be formalized by saying that every negative sentence contains an abstract negative operator with an interpretable negation feature that values the uninterpretable negative feature(s) borne by the one or more overt expressions of negation in the clause (cf. Penka 2007). An approach along these lines captures the fact that either $m \bar{a}$ or $-\check{s}$ or both together can express negation in certain Arabic varieties, without having to posit semantic ambiguity of either $m \bar{a}$ or $-\check{s}$. An approach that posited interpretable negative features on overt expressions of negation would have to posit such a feature for both $m \bar{a}$ and $-\check{s}$ in order to capture the fact that either can express negation alone, and then

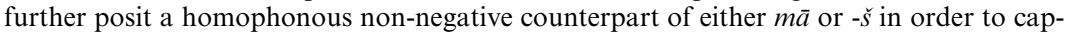
ture the fact that together they still express negation rather than double negation $(=$ affirmation). The latter approach would appear to be more stipulative and less elegant than the former. 
the last major wave of these came at the end of the Crusades. Thereafter, speakers of CMA became isolated from the rest of the Arabic-speaking world (although there has always been, of course, intensive contact with Cypriot Greek) and have remained so to this day (Lucas 2007: 409-4IO). As indicated in (6) (see also Borg 2004: 303), CMA is today (and therefore presumably always has been) stage I:

(6) mā-ruxt

NEG-gO.PRF.ISG

'I didn't go.'

(Cypriot Maronite Arabic - Tsiapera 1969: 68)

This suggests that the innovation of the stage II construction in Arabic took place in the dialects spoken in North Africa at some point after this region was conquered by the Arabs by the end of the seventh century. Evidence from two further varieties can help us to narrow down this observation somewhat in time and space. ${ }^{4}$

Firstly, there is evidence from Spanish Arabic. This variety was spoken in Spain until the Muslims and Jews were driven out in I492. Exceptionally among the medieval spoken Arabic dialects, we have a rather clear picture of Spanish Arabic thanks to a number of strongly colloquial-influenced texts that have come down to us from authors in that region. These show no sign of a stage II negative construction, as illustrated in (7). The reason that in this instance we can conclude with some confidence that this is an accurate reflection of the dialect spoken in Spain, and that it had in fact remained firmly at stage $\mathrm{I}$, is that one of the commonest negators in the relevant texts is a preverbal item $i \check{s}$ ( $<a \check{s}$ ' what' < ayy šay? 'which thing'; Corriente I977: I45, cf. etymology of $m \bar{a}$ above). This is a striking colloquialism, completely absent in Classical Arabic, and it seems unlikely that these authors would have seen fit to include this facet of their colloquial negation system in their writings while excluding a hypothetical stage II construction.

(7) iš tanfạ al-wașiyya

NEG be.of.value.IMPF.3FSG the-advice

'The advice is useless.'

(Spanish Arabic - Corriente I977: I45)

[4] An anonymous reviewer notes that the development of stage II negation in North African Arabic can be dated relative to other linguistic changes as well as to historical events. For instance, concerning the change $-k i>-i k$ in the form of the second person feminine singular pronominal suffix, North African dialects west of Egypt have lost the older form -ki altogether, and this presumably occurred before the arrival of stage II negation in these varieties. This seems likely because, in varieties such as Cairene which retain $-k i$ as a phonologically conditioned allomorph of the new base form $-i k$, the presence of negative $-\check{s}$ following the pronominal suffix is one of the primary triggers for the appearance of $-k i$ (thus $-k i-\breve{s})$. Had the North African varieties west of Egypt not lost the older -ki allomorph before the development of stage II negation, one might expect that they too would have retained it preceding $-\check{s}$ until today, as is the case in Cairene. 
Given that Arab Spain was settled (from the second decade of the eighth century onwards) and then later ruled principally by inhabitants of what later became Morocco (Guichard 2000), one would expect the Arabic varieties spoken in the two regions to have been rather similar. Given further that the stage II construction has spread uniformly across coastal North Africa and beyond and that Spanish Arabic appears to have lacked this construction, it looks unlikely that it became a feature of Moroccan Arabic until after the initial period of settlement in Spain. If we can find evidence suggesting a relatively early development of the stage II construction elsewhere, then we have grounds for excluding Moroccan Arabic at least from the list of likely candidates for the origin of the Arabic stage II construction.

Such evidence comes from Maltese, which, as mentioned above, today features the same stage II construction as we find in mainland North African Arabic varieties. This is significant because, on the reasonable assumption that Maltese did not independently innovate precisely the same negative construction as in other stage II varieties (see Lucas 2007 for finer points of the similarity between Maltese and mainland North African Arabic negation), it suggests that the Muslims who settled in Malta spoke a dialect that already featured the stage II construction. Most of these settlers appear to have come from Tunisia via Sicily, and there were extensive trade links between these three countries during the period of Arab rule in Malta from 87I to I09I. In II27, however, Malta was taken by the Normans, and by I248 they had expelled the last of the Muslims (Cassar 2000: 59-60). Since that time and until recently there has been little contact between the Christian Arabic speakers on Malta and the speakers of other Arabic varieties.

Taken together, then, these facts suggest that the stage II construction had reached Maltese by the start of the twelfth century at the latest and Tunisian Arabic at some point prior to this, while Moroccan Arabic lacked this construction until some later period. This conclusion must of course be seen as tentative in the absence of solid textual evidence, but it should nevertheless prompt us to look further eastwards for evidence for the origin of the stage II construction, i.e. in some North African Arabic variety east of Morocco.

The next section gives an overview of negation in Coptic, particularly in its later stages (after the Arab conquest of Egypt in the seventh century), in order to establish whether the Coptic origin of the Arabic stage II construction is a workable hypothesis.

\section{Coptic sentential negation}

\section{I Overview}

Coptic is the latest stage of the Ancient Egyptian language, and shares many features with its Late Egyptian predecessor Demotic, being distinguished from the latter chiefly by its Greek-derived script. Coptic texts are found 
from the first century onwards, but Coptic is thought to have died out as a spoken language by the sixteenth century at the latest (Watterson I988), though it continues even today to be used in the liturgy of the Coptic Church.

Sentential negation in Coptic is accomplished through a complex set of constructions that are sensitive to various factors such as tense, modality, predicate type and predicate definiteness (in the case of nominal predicates). Only a cursory overview of this intricate system will be given here.

Coptic is predominately an SVO language and is heavily prefixing. Verbal constructions are usually AuxSVO, with the auxiliary expressed as a proclitic on the subject. ${ }^{5}$ The subject may be either a full nominal expression or a pronominal prefix, as shown in $(8 \mathrm{a}, \mathrm{b})$ :
(a) a-i-cine om pa-eiōt
PRF-ISG-find ACC my-father
'I found my father.'
(b) nere-p-rōme kōt on ou-ēi
IMPF-the-man build ACC INDF-house
'The man was building a house.'

In negative contexts, two main strategies are used. Either a negative particle (encoding simply negation) is added to the auxiliary/verb, which otherwise remains as it would be in non-negative contexts; or a special negative auxiliary (encoding other features such as tense in addition to negation) replaces the affirmative auxiliary. The negative particle strategy is used with the present, imperfect and future tenses as well as certain constructions having causative or various temporal/conjunctive meanings (i.e. 'until', 'then', 'when', 'and so' + verb) and in several types of complement clause. The negative auxiliary strategy is found replacing the habitual, optative and perfect affirmative auxiliaries. The following examples illustrate the range of possibilities available for negation. The auxiliary strategy is illustrated in (9a, b), which demonstrate the affirmative perfect auxiliary, $a$, and the negative perfect auxiliary, ompe, respectively.
(9) (a) a-f-ouōšt na-i
PRF-3MSG-worship DAT-me
'He worshipped me.'
(b) əmpe-f-ouōšt na-i
PRF.NEG-3MSG-worship DAT-me
'He did not worship me.'

(BC.J I0.3)

(BC.J I0.6)

Two manifestations of the particle strategy are shown in (IOa), which is imperative, and (Iob), which is a form known as the 'past temporal', respectively. Here, the negative elements are əmpər and təm respectively.

\footnotetext{
[5] One exception to this is the future tense, which is normally formed by prefixing na- directly to the verb.
} 
(Io) (a) əmpər-lupe əm pe-k-həmhal

NEG-aggrieve ACC M-2SG-servant

'Do not cause your servant grief.'

(b) ənter-i təm cine əmmo-f a-i-rime

(BC.J 36.6)

TEMP-ISG NEG find ACC-3MSG PRF-ISG-weep

'When I did not find him, I wept.'

Finally, examples (IIa, b) also demonstrate the particle strategy, this time with the stage II construction on ... an, which is what we will be focusing on primarily in what follows.

(II) (a) on ti-ouōš dōron onto'ot tēuton an

NEG ISG-desire gift from you NEG

'I do not desire a gift from you.'

(b) on ti-na-tsabo-ou an e-amənte

NEG ISG-FUT-teach-them NEG on-hell

'I will not teach them about hell.'

(BC.J 66.3)

Although the on ... an form of the particle strategy shown in (IIa, b) is only one of the many different negative constructions found in Coptic, there is a case for saying that it is the unmarked construction, in that it alone is used in the negation of the present, imperfect and future tenses, as well as with clauses of attendant circumstance, and certain of the so-called 'second tenses', which place strong emphasis (or perhaps more accurately, focus) on some element in the sentence (other than the verb), frequently an argument or adverbial element (Lambdin I982: 52, Reintges 2004). It is also the only option in the negation of verbless sentences (Loprieno I995: I4I):

ən anon ən-šēre on-t-həmhal an
NEG we the-children of-the-slave.woman NEG
'We are not the children of the slave woman.'

(Gal 4:3I)

As such, it seems reasonable to wonder whether the presence of this construction in Coptic might have played a role in the development of the superficially similar Arabic construction (shown in (4) above), particularly in view of the conclusion reached independently in section 2, that the Arabic stage II construction was developed in a North African variety east of Morocco between approximately the seventh and eleventh centuries, the Arabs having conquered Egypt in the mid-seventh century.

In and of itself, however, the superficial resemblance of the Coptic and Arabic stage II constructions clearly tells us nothing about the role of the former in the development of the latter. Moreover the resemblance appears to be no more than superficial: note that the placement of the Coptic postverbal negator an is rather different to that of its Arabic counterpart $-\check{s}$. In Arabic verbal sentences $-\check{s}$ always cliticizes to the end of the verb (as in (4) and (5)), with only pronominal object clitics potentially intervening. This 
word order is attested in Coptic, as in (IIb), but the more usual order is illustrated in (IIa), with an occupying clause-final position. Furthermore, from what we know of the etymology of an, it is quite different to that of Arabic -5 : an is generally agreed to be descended from an item $i w n 3$, which first appears in Late Egyptian texts, where it functions as a strong negative polarity adverb 'at all' (Gardiner I904). Its earlier history is unknown. As such, Arabic $-\check{s}$ (< $<\check{s} a y$ ? '(any)thing') cannot be a calque on Coptic an. Finally, we are faced with the fact that from an early period we find stage III negative constructions in Coptic appearing alongside the more conservative stage II construction. That is, the innovative Coptic postverbal negator an has become able to express negation alone, without the obligatory presence of the original preverbal negator on, which has become optional, at least in some contexts.

On this issue, Kickasola (1975: 272) claims, without referring to any specific time period, that the first negative element in the stage II construction, on, can be omitted wherever it can occur. This appears already to be true several centuries before the arrival of the Arabs in Egypt, to judge from third- or fourth-century ${ }^{6}$ examples such as (I3), where the focus of negation - the clefted subject anon 'we' - is not preceded by on. It is thus vital to know whether the stage III construction had increased significantly in frequency at the expense of the older stage II construction by the time the Arabs arrived in the seventh century and the Copts started learning Arabic in large numbers in the following centuries.

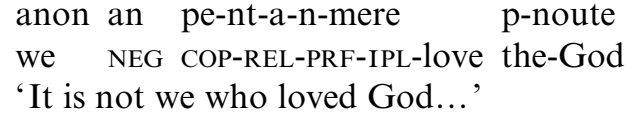

(I John 4: IO)

If the stage III construction had become unmarked in the relevant contexts by the time large numbers of Copts began learning Arabic as an L2, it is hard to see how or why they should have imposed a stage II construction on their L2 Arabic. Indeed, studies of the L2 acquisition of negation such as Stauble (I984) and Meisel (I997) show that native speakers of VNeg languages such as Japanese do not differ from native speakers of $\mathrm{NegV}$ languages such as Spanish with respect to their placement of negation in their L2 English, which is preverbal in all cases. That is, speakers of stage III languages do not appear generally to impose a stage III construction on a stage I L2. ${ }^{7}$ By the same token, we would not expect speakers of a stage III language to impose a

[6] On the dating of the Sahidic New Testament, see the entry 'Coptic versions of the Bible' in the Catholic Encyclopedia: http://www.newadvent.org/cathen/I6078c.htm.

[7] There may be exceptions to this generalization, particularly in cases of radical underexposure to the lexifier language in pidgin and creole formation. A referee points out, for example, that the Ugandan variety of East African Creole Arabic has a stage III construction with clause-final $m a$, probably as a result of substrate influence. Of course, to the extent that native speakers of stage III languages can impose stage II or III constructions on 
stage II construction on a stage I L2 either. Thus it is crucial to ascertain whether Coptic in its late stages was in fact solidly stage III in the relevant negative constructions, that is, whether the original preverbal marker had become obsolete. The corpus study presented in the following section was designed to ascertain whether this was in fact the case.

\subsection{Corpus study}

For the purposes of this study, a corpus of Coptic texts from the ninth and tenth centuries was compiled. This time period was chosen in order to reflect the language spoken in Egypt at the beginning of Arab dominance in the area. It should be stressed from the outset, however, that in trying to gain insight into the state of the spoken language of this period, we face the familiar problem that the texts used are likely to represent a more conservative register than one would have found in everyday speech. That said, Li speakers of Coptic would have been learning Arabic as an L2 for several centuries by the time these texts came to be written down. So it is perhaps no bad thing for current purposes if the texts represent to some extent the speech of earlier generations.

The texts are all religious in nature and written in Sahidic, a dialect spoken originally in the region of El-Ashmounein in the central part of the modern state of Egypt. This dialect was the main literary variety of Coptic from the third to the ninth centuries and survived until the fourteenth, when it was replaced by Bohairic, the standard language of the modern Coptic Church.

The texts used are as follows. First, the Martyrdom of St Coluthus (C), Paese and Thecla (PT) and Shenoufe and His Brethren (SB), collected and edited in Reymond \& Barns (1973). The manuscripts of these texts contain colophons explicitly dating them to the mid-ninth century (Reymond \& Barns 1973: 20). Additionally, three translations from Greek of Basil of Caesarea's sermons were used, namely, the Encomium on St Mercurius (M.B) (explicitly dated 842), the First Homily on St Michael Archangel (MA.B) and the Second Homily on St Michael Archangel (2MA.B), both of which can be confidently dated to the ninth or early tenth centuries (Depuydt 199I: viii). Finally, three translations also from Greek of sermons by John Chrysostom were also included. These are the Encomium on the Bodiless Creatures (BC.J) (explicitly dated 892-893), The Homily on St Michael Archangel (MA.J) (9th/early Ioth century) and the Homily on the Resurrection and the Apostles (RA.J) (explicitly dated 855). Our source for all of these texts was Depuydt (I99I).

From each of these texts, all of the negative sentences were excerpted and categorized according to negation type. The main focus of the corpus study,

stage I L2s, doubt that Copts could have been partly responsible for JC in Arabic is reduced still further. 
C PT SB M.B MA.B 2MA.B BC.J MA.J RA.J Total

\begin{tabular}{lrrrrrrrrrr}
\hline$\%$ on ... an & IOO & 85 & 97 & 67 & 54 & 80 & 55 & IOO & 56 & 83 \\
$\%$ an & 0 & I5 & 3 & 33 & 46 & 20 & 45 & 0 & 44 & I7 \\
$\begin{array}{l}\text { Total } \\
\text { tokens \# }\end{array}$ & I9 & 40 & 34 & 6 & I3 & IO & II & II & 9 & I53 \\
\hline
\end{tabular}

Table I

Percentages of stage II and stage III negative constructions in the corpus

however, was to track the presence or absence specifically of the first element in the two-part negation on ... an. If the stage II construction was still alive and well in the Li Coptic of L2 learners of Arabic, then this should mean that the proportion of occurrences of an with a preceding on in our corpus should be greater than that of an with no preceding on (i.e. a stage III construction).

This was indeed our finding for all texts in the corpus: no text had more occurrences of $a n$ without on than with it. Table I gives the percentages found in the corpus for each of these two variants.

If the stage II construction thus remains unmarked with respect to the stage III construction even at this relatively late stage, then what explains the presence of a small proportion of the latter in almost all of the texts? It was mentioned above that Kickasola (1975: 272) claims that the stage III construction (an alone) may be found wherever the stage II construction (on ... an) would have been possible. He also notes, however, that the distribution of these two alternatives is not entirely random. Although he does not provide statistics, he claims that on is more often omitted before nominal subjects than pronominal subjects. Where it is omitted before pronominal subjects, he notes that this occurs most often before $s e$ 'they', $t i$ ' I', and teton 'you' (plural). This is arguably a phonological phenomenon as all of these begin with coronal consonants, to which the coronal in on might be expected to assimilate. ${ }^{8}$ Kickasola also notes that on is omitted almost without fail before the imperfect-tense auxiliary ne(re) and is apparently inadmissible before the second perfect tense auxiliary onta (see (I6) below). These again appear to be phonologically motivated omissions.

In our own corpus, it turns out that every instance of a stage III construction where a stage II construction would have been expected is similarly attributable to phonological considerations.

First of all, the majority of cases of $ə n$-dropping are before a nasal. This is true whether or not the $/ \mathrm{n} /$ is a prefix or an integral part of the word. Thus

[8] The full story may be more complex, however, because Kickasola does not mention the frequency of occurrence of $2 n$ (or lack thereof) before ton 'we', which also begins with a coronal. 
examples (I4) and (I5) below have initial $/ \mathrm{n} /$ immediately following the position where one would have expected on to occur, be it the initial $/ \mathrm{n} /$ of the subject nekbasanos in (I4) or the initial /n/ of an auxiliary, as in neunapahtof in (I5). Dropping the negator before an initial nasal accounts for $15(58 \%)$ of the 26 attestations of $a n$ with no preceding on. In the following examples, the notation $(\partial n)$ indicates the position where this morpheme would be expected, were it present.

(I4) (ən) nek-basanos na-eš-cəmcom ero-i an

NEG your-tortures FUT-able-find.strength to-me NEG

'Your tortures will not be able to have power over me.' (PT 66Ri)

(I5) (ən) ne-u-na-paht-əf an ejō pe

NEG IMPF-3MP-FUT-pour-it NEG over.2FSG PRT

'It would not be poured over you.'

(PT $70 \mathrm{Vi})$

The second-highest percentage of on dropping was found before syllables which themselves begin with/on/. The two main contexts for this are with the negative of the second perfect, whose auxiliary is onta, and before second and third person independent personal pronouns, which all begin with the sound /ont/. Examples (I6) and (I7) show these two contexts. This accounts for six $(23 \%)$ of the total 26 attestations without an.

(i6) (ən) ənta-i a'a-u an hən oumənt-magos

NEG PRF-ISG do-them NEG by magic

'It is not by magic that I did them.'

(SB II9Rii)

(I7) (ən) əntetno an

NEG you NEG

'It is not you.'

The third group, with three attestations (or II \% of the total), was following the morpheme $e$, which is the circumstantial complementizer used to introduce clauses of attendant circumstance (see section 3.I). In this case one would have expected the pre-verbal negator, were it present, to appear as $n$ directly before the subject. Example (I8) shows an attestation of this type from the corpus. Finally, there are two examples $(8 \%)$ of omission of $2 n$ before a subject pronoun beginning with a non-nasal coronal. One of these is shown in example (19).

ouəngoun e $\quad$ (n) $k$-ər $\quad$ sa $\quad$ an
certainly COMP NEG 2 MSG-do celebration NEG
"While you are certainly not celebrating ...

(I9) (ən) ti-ouo:š an

NEG ISG-desire NEG

'I do not want ...'

(MA.B 2I.3)

Table 2 summarizes the environments in which $ə n$ is retained and where it is dropped. It emerges that the dropping of $2 n$ appears to be primarily a 


\begin{tabular}{lcccccr}
\hline & $\begin{array}{c}\text { Pre- } \\
\text { nasal }\end{array}$ & $\begin{array}{c}\text { Pre-ən[t], } \\
\text { etc. }\end{array}$ & $\begin{array}{c}\text { Between } \\
e \text { \& verb }\end{array}$ & $\begin{array}{c}\text { Pre- } \\
\text { coronal }\end{array}$ & Other & Total \\
\hline \# ən ... an & 2 & 0 & 7 & 59 & 59 & I27 \\
\# ... an & I5 & 6 & 3 & 2 & 0 & 26 \\
\hline
\end{tabular}

Table 2

Environments for on-retention and dropping

phonological process, at least in origin. on only seems to be dropped in the immediate environment of sounds with which it shares place and/or manner features. ${ }^{9}$ Furthermore, the only environment that appears actually to be conducive to on-dropping is before nasals (including nasals immediately preceded by schwa). All other environments favour on-retention.

Thus it seems reasonable to say that the Coptic stage II construction with on ... an remained the unmarked construction with respect to its stage III counterpart (and arguably also with respect to the various alternative negative strategies listed in section 3.I above) even at this late period, several centuries after the Arab conquest of Egypt and the time when Li Coptic speakers would have begun learning Arabic as an L2.

What, then, are the arguments for and against the presence of this stage II construction in the LI grammars of these individuals having led to the transfer of this structure to their L2 Arabic? The following section explores this possibility from an external point of view, while section 5 shows how such a process of transfer might best be modeled psycholinguistically.

\section{THE CASE FOR CONTACT}

Generally speaking, there appear to be two main approaches taken by those arguing against a role for language contact in a given syntactic change such as the one at issue here. These are, first of all, to insist that, as long as a given change could reasonably be envisaged as having taken place for purely internal reasons, an external explanation ought to be dispreferred, as it is less parsimonious (cf. Lass 1997: 209); and secondly, to accentuate any subtle differences that lie beneath the surface similarity of two constructions in two languages said to be linked by transfer. These seem to be perfectly valid ways of proceeding in matters such as this, and would appear to be particularly pertinent in the present case; indeed, we have highlighted the fact that JC is a

[9] The tokens of $2 n$-dropping following the complementizer $e$ perhaps have a non-phonological cause, which cannot be explored further here. Suffice it to say that even if ondropping can occur independently of phonological considerations in these texts, this is a distinctly marginal possibility. 
relatively common phenomenon, at least in the languages of western Europe, and also that the structural differences between the Coptic and Arabic stage II constructions are in fact not particularly subtle. However, there is reason to think that neither of these circumstances is as damaging to the case for contact here as they might at first appear.

To start with the structural differences between the Coptic and Arabic stage II constructions, we have already noted that the position of the innovative element $(-\bar{s})$ in the Arabic stage II construction is fixed in verbal sentences - it is enclitic to the verb, attaching directly to it or to any direct or indirect object pronominal clitics which may intervene:
mziyya mā gāl-ha-lū-š
rājol
lucky NEG say.PRF.3MSG-it-to.him-NEG man
'Luckily it wasn't a man that told him it.'

(Algerian Arabic - Elhalimi 1996: 138)

In Coptic, by contrast, the position of the innovative element an is much freer (though always appearing after the negated element), and, unlike Arabic, appears generally to follow any nominal direct object. Coptic places such a nominal object directly after the verb (which appears in a special prenominal form) or directly after a case-marking preposition. This is shown in (2Ia, b). If the object is a pronoun, it may be suffixed to the verb or it may be suffixed to a case-marking preposition.
(a) ən f-oueš p-mou gar an
NEG 3MSG-desire the-death for NEG
'For he does not desire death.'
(b) on g-na-he e soure an
NEG 2MSG-FUT-find ACC thorns NEG
'You will not find thorns.'

(MA.J 20.6)

(2MA.B 5.I)

In contrast to the general trend, however, in the largest of the texts in our corpus, Paese and Thecla (PT), we find a sizeable proportion of attestations $(29 \%)$ in which an precedes the verbal complement (whether an NP or a PP): ${ }^{10}$

(22) (a) ən ti-sooun an əm pe-hoou

NEG ISG-know NEG ACC the-day

'I do not know the day.'

(PT 82Vi)

[Io] an also shows variable order with regard to prepositional adjuncts, which may appear either to the left or the right of the post-verbal element:
(i) on ti-na-š-ka $\quad$ rō-i $\quad$ ero-s an
'I will not be able to keep silent about it.'
(ii) on ti-na-ka rō-i an ero-s
NEG ISG-FUT-keep silence-ISG NEG to-it
'I will not keep silent about it.'


CHRISTOPHER LUCAS \& ELLIOTT LASH

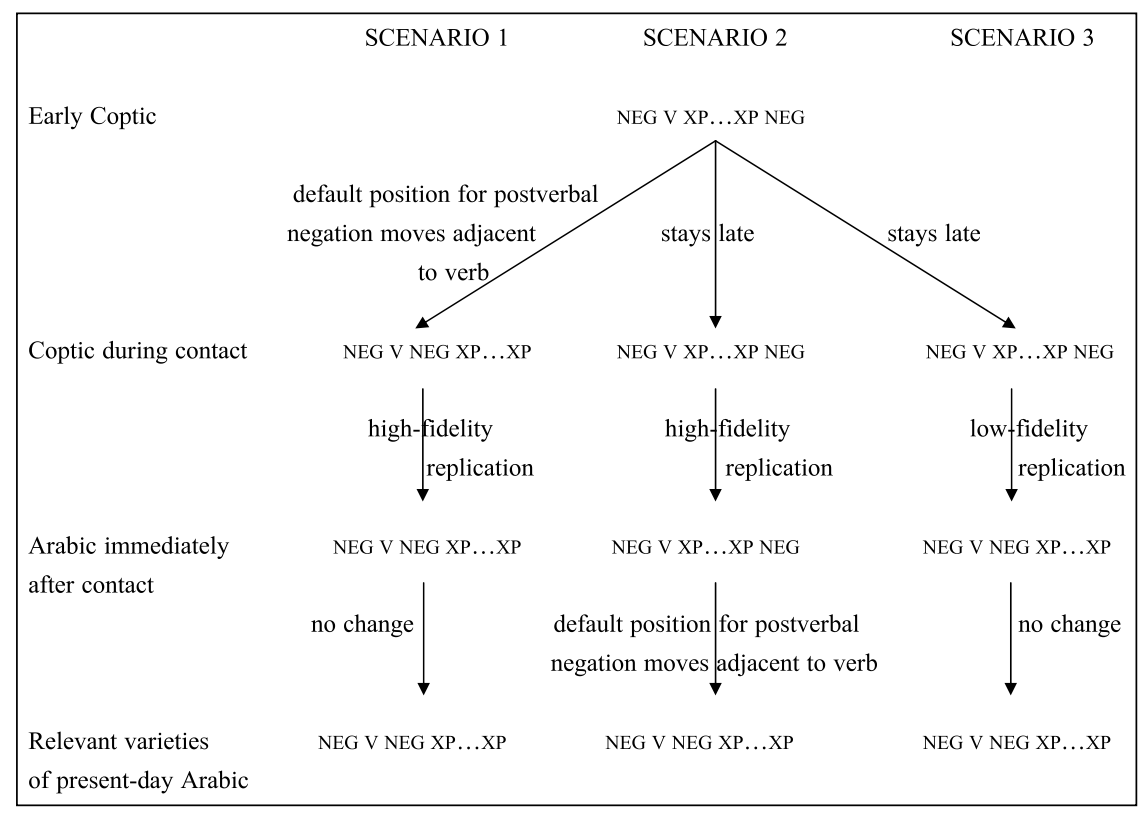

Figure 3

Three scenarios for the transfer of the stage II construction from Coptic to Arabic.

(b) ən ti-mpša an on pei-noc

NEG ISG-be.worthy NEG of this-honour

'I am not worthy of this honour.'

(PT 70Vi)

These data are suggestive of a move on the part of the ninth-/tenth-century variety of Coptic studied in our corpus towards a repositioning of an higher in the clause. This process, whereby a newly grammaticalized negator descended from an adverbial element (as seems to be the case for Coptic an-see section 3.I) starts off late in the clause but over time is more and more frequently found close to the verb, is familiar from the history of European languages such as French (Rowlett 1998) and Welsh (Willis to appear). ${ }^{11}$ If we are to maintain that the presence of a stage II construction in Arabic was in fact triggered by its somewhat different Coptic counterpart, a number of alternative possibilities, illustrated in figure 3 above, thus suggest themselves. First (scenario I), it could be that Li speakers of Coptic already felt in the period in which they started learning Arabic as an L2 that the

[II] This gradual migration of a clause-late negator to immediately postverbal position need not be inevitable, however, particularly where the negator in question is of the resumptive kind found, for example, in Brazilian Portuguese (Schwegler I988), Hausa (Van Gelderen 2008), and Modern South Arabian (see the discussion immediately following example (27)). 
default word order in Coptic negative sentences was for an to precede NP and PP complements of the verb. Under such a scenario they could then be said to have faithfully replicated this pattern in their L2 Arabic. Second (scenario 2), we could suppose that LI Coptic speakers at this time in fact still felt that the default order was for verbal complements to precede an, and that, again, they faithfully replicated this pattern in their L2 Arabic. However, in the centuries following this transfer Arabic followed French, Welsh and Coptic in increasingly raising its postverbal negator beyond verbal complements until adjacency to the verb became obligatory as it is now. Finally (scenario 3), perhaps most plausibly, it could be that Li Coptic speakers did not in fact faithfully replicate the principal Coptic pattern (with a clause-late negator) in their L2 Arabic (with a verb-adjacent negator). What they did instead was to interpret the Arabic they were exposed to in such a way that they found evidence in it for a stage II negative construction familiar to them from their LI, with the difference that in Arabic (or the version of it that they learnt at least) there was no optionality in the positioning of the postverbal element: it had to be verb-adjacent. Under this scenario (which will be developed in section 5) contact plays an important role in the development of the Arabic stage II construction, but this does not entail the perfect replication of the Coptic structure in Arabic.

But given that JC is not particularly unusual in the histories of the world's languages, do we need contact to 'explain' the development of Arabic stage II negation at all? To answer this question, it is important to consider why it is that some Arabic dialects have participated in this innovation while others have not. If we again consult figure 2, we see that stage II negation is found in a contiguous region across the more northerly part of North Africa, spilling over a little way into the Levant, and then, somewhat incongruously, in a second region in the southernmost part of the Arabian Peninsula (parts of modern Yemen and Oman). Let us first address why it is that stage II negation is not found throughout the Arabic-speaking region, and then why it is found precisely in those regions just mentioned.

Recall from section 2 that the Arabic postverbal negator $-\check{s}$ is ultimately derived from the Classical Arabic word say? 'thing'. Several features of the syntax of Classical Arabic make it look like a rather fertile breeding ground for JC. Firstly, Arabic has never had an indefinite article. As such, a nonreferential or quantificational interpretation of a noun of minimal quantity in Classical Arabic, such as $\check{s} a y ?$, is available synchronically in negative polarity contexts (23a), while in affirmative contexts apparently the same item retains its referentiality (23b):

(23) (a) xalaqtu-ka

min.qablu wa-lam taku

šay?an

create.PRF.ISG-you before and-NEG be.JUSS.2MSG anything.ACC 'I created you before, when you were not anything (/nothing).'

(Qur'ān I9: 9) 
(b) laqad jiPta šayPan nukran

PRT do.PRF.2MSG thing.ACC horrible.ACC

'You have done a horrible thing.'

(Qur'ān I8: 74)

Secondly, already in the Classical period we find examples of šay? apparently functioning as an adverb, rather than an argument.
(24) lā yaḍurru-kum kaydu-hum šay?an
NEG harm.IMPF.3MSG-you cunning-their at.all
'Their cunning will not harm you at all.'

(Qur'ān 3: I20)

It would appear, then, that by this stage šay? had already split into two (homophonous) items: the nominal use illustrated in (23) and the adverbial use in (24). This split would have been facilitated by the fact that the suffix marking indefinite accusative case in nouns is identical to the suffix that marks adverbs: - an. Moreover, it turns out that the form šay?an, whether functioning as an argument or an adverb, is found predominantly in the context of negation already in Classical Arabic. In the Qur'ān, for example, which consists of approximately 80,000 words, šay?an occurs 77 times. Of these, fully 63 $(8 \mathrm{I} .8 \%)$ occur in the scope of negation. Given this strong association with negation already in Classical Arabic, it would not then come as a surprise to find either the indefinite pronoun or the negative polarity adverb šay? grammaticalizing as a new postverbal negator; and this does appear to be what has happened in the stage II varieties spoken in the regions indicated in figure 2.

It is clear, however, that these features of Classical Arabic cannot represent sufficient conditions for the future development of a stage II negative construction, because not all of the modern dialects descended from Classical Arabic (or, perhaps more accurately, the Arabic spoken in the classical period; Owens 2006) have developed such a construction. A range of varieties have developed other functional items from Classical Arabic $\check{s} a y$ ? , but none of these can be seen as sufficient to trigger the subsequent development of a stage II negative construction, because they are found both in some dialects which have undergone JC and in some which have not. For example, in several dialects we find a clause-final element $\check{s} i(<\check{s}$ ay? $)$ which marks interrogation (not negation). It is found both in Syrian Arabic (Cowell I964) and Cypriot Maronite Arabic (Tsiapera 1969), which have not undergone JC, and, among those dialects which have, in Libyan Arabic at least:

\section{(25) šift ạmad amis ši \\ see.PRF.2MSG Ahmad yesterday Q}

'Did you see Ahmad yesterday?' (Libyan Arabic - Owens I984: I02)

Similarly, $\check{s} i(<\check{s} a y$ ? $)$ is found with the function of an adnominal quantifier 'some X' in both Moroccan Arabic, which has undergone JC, and Syrian Arabic, which has not.

For a contact-based account of the development of JC in Arabic to be discounted, there needs to be a coherent internal account which could 
replace it. The onus is on an internal account, which claims that various features of Classical Arabic were sufficient to cause this development, to explain why they were only sufficient for a subset of the dialects descended from Classical Arabic (or something like it). In the absence of such an explanation, the contact-based explanation suggested here seems to be more warranted in view of the facts available. Indeed, this contact-based explanation is given stronger support once we turn to consider why it is that the dialects of Arabic which have undergone JC are distributed the way they are.

Their distribution in the region stretching from Morocco to Palestine and neighbouring areas of surrounding countries is unproblematic if we assume an Egyptian origin, followed by spread via dialect contact. JC would have spread westwards from Egypt throughout coastal North Africa, following the prevailing flow of migration of Arabic-speaking peoples in this region and consistent with the sphere of influence of Cairo as the capital of the Fatimid empire in the tenth to twelfth centuries. Recall from section 2 that the evidence from Spanish Arabic suggests a relatively late date for JC in Moroccan Arabic, which is entirely in keeping with a scenario that sees the stage II construction spreading gradually westwards from Egypt. Similarly, it makes sense that this construction should have spread only a little way eastwards into the Levant as this is against the prevailing flow of migration (Taha 1989).

The presence of stage II and III constructions in the south of the Arabian Peninsula, on the other hand, at first sight represents something of a conundrum. Lucas (2007: 4I5-4I6), following Obler (1990: I48), makes the somewhat unsatisfactory suggestion that JC spread here through sea trade contacts with Egypt. A second, somewhat more plausible scenario, some of whose difficulties are discussed at the end of this section, sees JC as originating in the south of the Arabian Peninsula and being brought to North Africa by migrants of Yemeni origin. The third possibility, which we argue for here, sees the presence of JC in the south of the Arabian Peninsula as a development separate to JC in North Africa, albeit similarly contactinduced-this time involving contact with the Modern South Arabian languages, which have themselves also undergone JC.

The Modern South Arabian languages are a group of closely related languages spoken primarily in the border region between Yemen and Oman. They form a branch of South Semitic, most closely related to the Ethiopian Semitic languages and sufficiently different from Arabic as to be incomprehensible to monolingual speakers of the latter (Simeone-Senelle 1997: 378).

The most conservative Modern South Arabian language with respect to JC is Soqotrii, spoken on the Yemeni island of Soqotra, where negation is realized by a stage I construction:

(26) ol fśek

NEG lunch.PRF.ISG

'I didn't eat lunch.' (Soqoṭi - Simeone-Senelle I997：4I4) 
The mainland varieties are either stage II or stage III. The former is represented here by Jibbāli, spoken in the mountains of Dhofar in southwestern Oman:

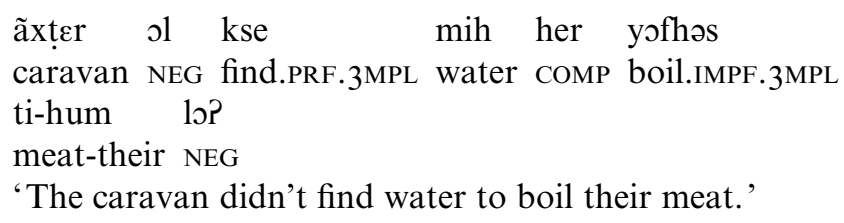

(Jibbāli - Simeone-Senelle 1997:4I3)

Note, as in Coptic, the late position of the postverbal element lo?, which here follows even the embedded clause. loP/la? are the postverbal negators in all the stage II/III Modern South Arabian varieties, and in most of these the anaphoric negator 'no' is also la?. It seems likely that this la? 'no' was reanalysed as a clause-final negator in 'resumptive' contexts where it was appended to the end of a sentence in either declarative contexts ('I don't like that, no') or in tag questions ('You didn't like it, no?'), as suggested by Schwegler (1988) for the similar Brazilian Portuguese construction. Among the stage II varieties, in Jibbāli at least, the sentential negator lo? appears to be fully grammaticalized as a negator rather than, for example, as a negative polarity adverb, since it must occur in all negative contexts (with the exception of prohibitive sentences). Indeed, $l o$ P rather than $s l$ would appear to be the 'true' negator as the latter can appear pleonastically in non-negative downward-entailing contexts such as the VP-complement of verbs of fearing (compare French ne):

$\begin{array}{lll}\text { šeh tekəl } & \text { ol } & \text { yġad } \\ \text { he } & \text { worry.PRF.3MSG } & \text { EXPL.NEG } \\ \end{array}$

'He was worried about going.'

(Jibbāli - Johnstone I98I: 2)

Several Modern South Arabian varieties have in fact moved well into stage III of JC, maintaining the preverbal marker only in a restricted set of contexts. For example, Johnstone (1977:2) remarks of Harsūsi (also spoken in Dhofar) that ' $e l$ [the preverbal negator], however, is common only in the double negative: el ...w-el "neither ... nor", Otherwise we find a clausefinal stage III construction:

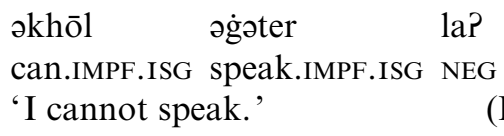

(Ḥarsūsi - Simeone-Senelle 1997：4I4)

In view of these facts and the above discussion of the non-contiguous distribution of stage II negative constructions in the Arabic dialects, there seems to be a reasonable prima facie case for saying that the stage II construction in Yemeni and Omani Arabic (as illustrated in (30)) was also 
triggered by contact, this time with earlier varieties of the Modern South Arabian languages.

(30) bih nās mā yịjib-hum-šs aš-šāy
there.are people NEG please.IMPF.3MSG-them-NEG the-tea
'There are people who don't like tea.'

(Ṣan'āni (Yemen) - Watson I993: 26I)

Assuming this to be the case, the arguments for contact as the trigger for JC in both the Arabic of North Africa and the south of the Arabian Peninsula now appear to be mutually reinforcing. Moreover, if this is accepted we also have double backing for the claim that contact can trigger syntactic changes whose results do not perfectly replicate the structure transferred from the source language. Recall that in both Coptic and Modern South Arabian the postverbal negator typically occupies a clause-late position, whereas in Arabic it is a verbal enclitic and thus precedes nominal and prepositional complements. At the same time the Arabic postverbal element cannot be described as a calque on either Coptic or Modern South Arabian, since the Arabic element is clearly derived from an indefinite pronoun, whereas this appears not to be the case for its counterparts in either of the two proposed source languages. So we see that the negative constructions found in Coptic and Modern South Arabian are rather similar, while both differ noticeably from that found in the relevant varieties of Arabic. Nevertheless, this clauselate bipartite negative construction found in both source languages appears to have given rise to the Arabic verbal enclitic construction on two separate occasions and in two separate locations.

An anonymous reviewer points out that positing independent parallel development of the same construction in two different varieties of the same language ought to be avoided where a plausible case for historical connectedness can be made (the claimed non-independence of the Maltese stage II construction from that of mainland North African Arabic in section 2 was based on the same reasoning). Specifically in the present case, it is known that Arab tribes said to be of 'Yemeni'12 origin were centrally involved in the conquest and settlement of Egypt (Owens 2003: 729). Therefore we should see the presence of JC in both North Africa and the southern Arabian Peninsula as linked by diffusion of a single innovation into the latter region.

Such a hypothesis has a good deal of initial plausibility, and it seems unlikely that any evidence could be produced that would force us to discount

[12] One should probably be cautious, however, in identifying the region inhabited by these tribes with the area occupied by the present-day Republic of Yemen. As Owens (2003: 729 fn. 26) points out: 'Qaysites may be taken as roughly eponymous for Arabs of eastern Arabian peninsular origin, Yemenis for western ... At this point in our study of the history of Arabic dialects, it would be premature to try to link these two broad groupings with specific dialect forms.' 
it altogether. Indeed, if there already existed a stage II variant in the dialect of some of the Arab settlers in Egypt, then we would expect this variant to have been reinforced by the presence of the parallel Coptic stage II construction, for the reasons given above. So accepting the possible correctness of this hypothesis in no way requires us to abandon the hypothesis of a role for Coptic contact in the development of North African Arabic negation. However, positing a purely Yemeni - and denying a Coptic - origin for JC in North Africa would appear to raise more questions than it offers answers, and, on its own, it would have to be viewed as a rather unsatisfactory explanation of the distribution of JC among the Arabic dialects.

First of all, the Yemeni origin hypothesis involves stipulating that stage II negation had developed in at least some Yemeni variety prior to the Arab expansion out of the Arabian Peninsula. We are not aware of any independent evidence supporting such a stipulation. On the other hand, if this stipulation were correct, and speakers of this variety were prominent enough in early Muslim society to be at the forefront of the aforementioned expansion, then one might expect some reference to stage II negation in the early Arab grammarians' discussion of variation in Arabic dialects, particularly given their interest in variation concerning other aspects of negation (cf. Owens 1988: 26). There does not appear to be any such reference, though of course this lack of evidence in no way proves the non-existence of stage II negation at this stage.

Taking the Yemeni origin hypothesis further, we are forced to ask once more, why do we end up with precisely the distribution of stage II negation among the Arabic dialects that we observe in figure 2? Specifically, why should stage II negation have taken root in Egypt but not in Iraq or Syria, where Yemeni tribes are also known to have been centrally involved in conquest and settlement? Concerning Syria in particular, Mad'aj (I988: 85) points out that

both early and modern historians confirm that the Yemenis formed the basis of the Muslim troops settling in Syria ... In fact the nature of the settlement of the Arabian tribes in Syria was different from that in Iraq and Egypt. In Iraq and Egypt they confined themselves to the garrison towns ..., while in Syria they settled in towns and villages throughout various regions (ajnād).

This being the case, the Yemeni origin hypothesis would have to introduce further stipulations to account for the unexpected absence of JC in Syria. For example, as the reviewer points out, Arabic came into intensive contact with the Aramaic varieties spoken by the local populations in Syria. Since Aramaic has only ever had stage I negation, and is structurally more similar to Arabic than Coptic is, it is conceivable that contact between the two favoured the conservative stage I construction and disfavoured the hypothetical innovative stage II construction. Again, this is a possibility that 
cannot be ruled out; but it seems at least as methodologically parsimonious to argue, as we have here, for independent parallel development under similar contact conditions, with no change in dialects that today lack a stage II construction, as it does to postulate a single development and explain its unexpected absence in various regions in an ad hoc fashion, or to leave it unexplained. ${ }^{13}$

Finally, the same reviewer adduces another piece of evidence in favour of the Yemeni origin hypothesis, namely that the stage II construction is 'morphophonologically specific and identical between Yemen and Egypt'. This refers to the effects that enclitic $-\check{s}$ may have on the length of a preceding vowel and the position of stress in the word. However, it is far from clear that these effects are either specific to $-\check{s}$ or identical in Yemeni and Egyptian Arabic. In Cairene Arabic, $-\check{s}$ causes a preceding short vowel to lengthen and shifts stress to the right (3ra), but this is true of all consonant-initial enclitics (3Ib).

(3I) (a) $\mathrm{ma}+$ 'gara + -š > maga'rāšs 'it didn’t happen' (NEG-happened-NEG)

(b) is-'sana + di $>$ issa'nādi 'this year' (the-year-this)

(Woidich 2006: 34-35)

As far as stress is concerned, consonant-initial enclitics in Yemeni Arabic in general have the same effect as in Cairene, but there are exceptions which have to do with phonological properties of the root rather than the affix (see Watson 2002: I02-I03 for details). Concerning vowel length, Watson (2002: I82) points out that, in the Yemeni variety she describes, 'short morphemefinal vowels are rarely attested, and therefore the constraint on pre-suffixal short vowels applies vacuously'. A further point of morphophonological non-identity concerns the resolution of a geminate consonant $+-\check{s}$ cluster in the two varieties. In Yemeni Arabic there is degemination (32a), whereas in Cairene there is epenthesis (32b).

[13] The same anonymous reviewer points out that stage II negation is absent in the Arabic of the Sudanic region, which is known to have been settled by migrants from Upper Egypt at some point after I225, indicating that the stage II construction cannot have spread throughout the whole of the Egyptian population by this time. However, these facts seem to us to be consistent with either the Yemeni or the Coptic origin hypothesis. Note in this connection that the people who brought Arabic to the Sudanic region were likely to have been nomadic pastoralists (Owens 2003: 722), and to this day the Arabic varieties spoken by Bedouin who maintain a nomadic lifestyle (or have done so until recently) tend overwhelmingly not to feature a stage II construction, even within regions where the stage II construction is the norm amongst sedentary Arabic-speaking communities (cf. Rosenhouse 1984: 515; Caubet 2000-I: 79; de Jong 2000: 223, 477). A fortiori, we would not expect the stage II construction to have been a feature of the varieties spoken by nomadic Arabicspeaking tribes in Upper Egypt in the early second millennium either, even though it would, by hypothesis, already have been a feature of the variety spoken by the autochthonous sedentary population of the same region. 
(32) (a) Yemeni: mā +habb +-šs $>$ mā habš 'he didn't like' (NEG-liked-NEG)

(b) Cairene: $\mathrm{ma}+$ habb + -š $>$ mahabbiš 'he didn't like' (NEG-liked-NEG)

(Watson 2002: 210)

Thus the morphophonological properties of enclitic $-\check{s}$ in Yemeni and Egyptian Arabic are similar, but not identical.

It seems to us, therefore, that while the Yemeni origin hypothesis cannot be ruled out at least as a contributing factor, the available evidence favours the Coptic contact hypothesis for the origin of JC in North Africa. Note in this connection that other cases of independent parallel development of essentially identical constructions under similar language contact conditions can be pointed out - for example, the use of bin as a preverbal (nonprogressive) past tense marker in a range of English-based creoles such as Tok Pisin (Verhaar I995: 3I3-Austronesian substrate), Gullah (Turner 2002 : 225 - West African substrate) and Kriol/Australian Aboriginal English (Eades I996: I34 - Australian substrate). Clearly here there is no temptation to say that the presence of this construction in all three of these creoles is the result of a single innovation within some earlier unrecorded variety of English. Of course, the existence of the English past participle been was a necessary condition for the development of past tense bin in all three cases, but it cannot be seen as sufficient: standard English, for example, has not developed this construction. The sufficient condition for independent parallel development of this construction in each case can be assumed to be the properties of the tense-aspect systems of the respective substrate languages. It will be seen that this line of argument is directly parallel to the one we have advanced in favour of the independent parallel development of stage II negation in North African and in southern Peninsular Arabic: similar contact-induced pressure to develop a stage II construction exerted on similar Arabic varieties spoken in two separate regions led to independent parallel development.

Just how contact might have helped to bring about this change in both these cases is the subject of the following section.

\section{THE MECHANISM OF CONTACT}

It seems likely that part of what underlies the (healthy) suspicion of those who prefer to seek internal explanations of linguistic changes over external ones is the fact that internal mechanisms of change are simply much better worked out than their external counterparts. Moreover, all too often those who do not share the aforementioned suspicion are liable to invoke contact as a brute, unexplained force, a kind of deus ex machina capable of almost anything (for a randomly selected example see the claim of contact with Semitic in the formation of Germanic verbal ablaut in Mailhammer 2007). The purpose of this final section is to work through in more detail just how it 
could have been that contact between Coptic and the Arabic spoken in Egypt led to a change in the expression of negation in the latter. ${ }^{14}$

The starting point for this proposal is Van Coetsem's (I988, 2000) distinction between source-language (SL) and recipient-language (RL) agentivity. An advantage that Van Coetsem's framework for contact-induced change has over many of the competing models is that it focuses primarily on the psychological characteristics of individual bilingual speakers of the languages in contact, rather than on sociolinguistic considerations. To be sure, a detailed understanding of the sociolinguistics of language contact is crucial for an account of what social conditions and social processes make contactinduced change possible in the first place. However, we follow Van Coetsem $(1988,2000)$ and Winford (2005) in seeing a true explanation of contactinduced change as consisting in an account of how contact leads to changes in the mental grammars of individual speakers. Van Coetsem's distinction offers a basis on which such an account can be built.

In Van Coetsem's model, influence of the SL on the RL is called 'transfer'. By definition this is always from the SL to the RL. For any kind of transfer to take place it is a prerequisite that at least some speakers have knowledge of and exposure to both of the languages in question. Such speakers we will call 'bilingual', with no implication intended in the use of this term that the speakers in question have native-like grammars of both languages. Speakers who do have native-like grammars of both languages we will refer to as 'balanced' bilinguals - a proper subset of the set of all bilinguals. It is clear that (ordinary) bilinguals thus defined must be the agents of contact-induced change. In fact, although there is by no means agreement on this point in the literature on bilingualism, it seems likely that balanced bilinguals will play a relatively minor role in contact-induced change, as, by definition, the grammars of each of their Lis do not differ in any bilingual-specific fashion from those of their monolingual contemporaries (Meisel 200I; for an alternative view see Döpke 1998). Our focus is therefore on bilinguals who are 'dominant' (psycholinguistically, not sociolinguistically speaking) in either the RL or the SL. For present purposes, let us define a bilingual speaker's dominant language as one whose production does not differ in any bilingual-specific fashion from that of a monolingual speaker of the same language, while a non-dominant language is one whose production does differ in a bilingualspecific fashion from that of a monolingual speaker. In most cases, then, if a bilingual's production of a dominant language does not differ in any bilingual-specific fashion from that of a monolingual speaker of the same language, it is because this is his or her $\mathrm{LI}$, acquired from birth. On the other hand, if a bilingual speaker's production of a non-dominant language does

[14] For present purposes we will assume that the processes that led to JC in the Arabic of Yemen and Oman were essentially the same as those described here for Egyptian Arabic, albeit with Modern South Arabian as the contact language rather than Coptic. 
differ from that of a monolingual speaker, this will generally be because it is his or her L2: a language which they were not, or only insufficiently, exposed to in childhood. ${ }^{15}$

On this basis it can be seen that there are two major possibilities for contact-induced change: that which is effected by speakers dominant in the RL (RL agentivity), and that which is effected by speakers dominant in the SL (SL agentivity). ${ }^{16}$ Van Coetsem calls changes that take place under RL agentivity 'borrowing' and those that take place under SL agentivity 'imposition'. From this perspective, the questions to be addressed with respect to JC in Coptic and Arabic are: which of the two types was operative in the transfer of Coptic negation to Egyptian Arabic, what provided the stimulus for this change, and how did it result in a change in the mental grammars of (eventually also monolingual) native speakers of Arabic?

Although the first of these questions is fundamental to a psychological account of this change, it is unfortunately impossible to answer it definitively given the paucity of information about the sociolinguistic situation in Egypt in the period in question. What information we do have, however, makes it reasonable to assume (as we have above: see discussion of figure 3 ) that this change occurred under SL agentivity. Firstly, it is clear that the long-term trend was for Coptic speakers to shift to Arabic and not vice versa, since Coptic eventually died out as a spoken language. This shift appears to have started early, at least in official discourse, as Arabic was substituted for Coptic in all state affairs already in 706 (Solihin I99I: I2) - though the Arabic used in official matters will of course have been an early form of Standard Arabic. Secondly, indications are that the Arabs remained a small militarypolitical elite for some considerable time in Egypt, and even if some of them did learn Coptic as an L2, these would have represented only a fraction of the numbers of Copts who learnt Arabic as an L2. The first significant wave of migration of Arab tribes such as the Banu Hilal and Banu Sulaym was not until the eleventh century (Abun-Nasr 1987) - at the end of, or after, the likely period for when this change took place (see section 2). Lastly, we noted in section 4 that the Arabic stage II negative construction cannot be considered a calque on that of Coptic, and structurally it is rather different. Even if there were Li Arabic speakers who learnt Coptic as an L2 and were thereby somehow prompted to replicate the Coptic stage II construction in their

[I5] It is theoretically possible, in cases of language attrition, that this correlation between LI and dominance, and L2 and non-dominance, could be reversed; but, in the present case at least, there is no evidence to suggest that significant numbers of Li Arabic speakers in Egypt subsequently had so little exposure to Arabic that they started to show signs of attrition and Coptic became their dominant language.

[16] It is also possible, of course, and perhaps even likely, that in any large-scale contactinduced change that affects an entire speech community, the change could have been effected by both RL-dominant and SL-dominant speakers separately. 
LI Arabic, how or why they should have recruited their indefinite pronoun for this purpose and made it immediately postverbal, rather than, say, recruiting an existing Arabic negator or borrowing Coptic an and keeping it in its predominately clause-late position, is unclear. By contrast, how and why L2 speakers of Arabic (with LI Coptic) should have done this receives a principled explanation as follows.

We follow Meisel $(1997,2008)$ and others in seeing the acquisition of L2 syntax as a process which draws on general cognitive learning strategies, so that second language learners, "rather than using structure-dependent operations constrained by UG, resort to linear sequencing strategies which apply to surface strings' (Meisel I997: 258). Clearly, however, knowledge of their LI is liable to exert a considerable bias in the operation of these linear sequencing strategies. Put simply, second language learners will come to an L2 expecting to find in it features they are familiar with from their Li. If they are met with strong evidence for the absence of a particular feature, they are unlikely to impose it. If, however, they do find what they take to be evidence for this feature, in the absence of correction they will be likely to impose it on their L2. Of course, on a view which sees Li acquisition as the task of a dedicated mental module, while L2 acquisition uses general cognitive learning strategies, it is to be expected that what counts as evidence of a feature for LI acquirers is quite different to what counts as evidence of a feature for L2 acquirers.

We propose that Li speakers of Coptic learning Arabic as an L2 did indeed find evidence in the Arabic they were exposed to for what to them would have seemed a 'natural' stage II negative construction. Sentences such as (33b), for instance, might provide such evidence.
(a) tašrab qahwa
drink.IMPF.2MSG coffee
'Would you like some coffee?'
(b) la mā ašrab šay? qabl an-nawm
no NEG drink.IMPF.ISG anything/NEG before the-sleep
Conservative interpretation: 'No, I don't drink anything before bed.'
Innovative interpretation: 'No, I don't drink (coffee) before bed.'

The conservative interpretation of ( $33 \mathrm{~b})$ is that the question is about coffee, whereas the answer is about anything, including coffee. If, however, an L2 acquirer were expecting to find negation expressed by two elements, one either side of the verb, it seems plausible that they could interpret šay? here as a postverbal negator and assume that (33b) features a null object, as would be common in Arabic and other languages when there is a salient referent in the discourse for such an object, such that both the question and the answer are about coffee on this interpretation. Recall also from section 4 that $\check{s} a y P(a n)$ functioning as an adverb or an argument in Classical Arabic is 
predominantly found in the scope of negation, making the innovative interpretation of ( $33 \mathrm{~b})$ all the more plausible.

Clearly such contexts would have been available in all varieties of Arabic and, in principle, children acquiring Arabic as an Li could have been just as susceptible to this reanalysis as were adult L2 learners. However, as we have seen, only a subset of Arabic varieties actually underwent JC. This must mean that contexts like that in (33) have, in fact, always been transparent to LI acquirers of stage I varieties: despite the apparent ambiguity, they have not found evidence to suggest that $\check{s} a y$ P is anything other than an indefinite pronoun (or adverb) here. It seems that only L2 acquirers of Arabic whose Li features a stage II construction are liable to find such contexts ambiguous and decide that they support an analysis of Arabic such that it too features a stage II construction.

However, L2 learners are still bound to some extent by the (surface) syntax of the tokens of the L2 they are exposed to. It is apparently only in cases of radical underexposure to the $\mathrm{L} 2$, if at all, that speakers will simply relexify their LI with its syntax completely intact (Lefebvre 200I). Ordinarily, there will be some syntactic features of the $\mathrm{L}_{2}$ that are sufficiently salient to the L2 acquirer such that they are not simply replaced by their equivalents from his or her LI. So it appears that in the present case, while native speakers of Coptic found evidence in structures such as (33b) that Arabic, like Coptic, also had a stage II negative construction, at the same time they also found evidence that in Arabic the postverbal element is routinely verb-adjacent, rather than occasionally so as in Coptic, so they did not simply transfer the syntax of their stage II construction wholesale into their L2 Arabic.

If sufficient speakers then incorporate these analyses into their production of their L2 Arabic, the conditions are there for this new hybrid construction to make its way into the Li grammars of Arabic speakers via child language acquisition. First of all, as use of Arabic became more and more common in the Coptic community, increasing numbers of children in this community will have acquired Arabic as an Li simultaneously with Coptic (cf. Meisel 200I on the simultaneous development of two LIs). The primary linguistic data on the basis of which these children acquired Arabic as an LI will have come partly from native speakers of Arabic, but an important component will also have stemmed from the L2 Arabic production of native speakers of Coptic. Assuming that these speakers' L2 Arabic speech contained the innovative stage II negative construction, this construction will also have formed part of the primary linguistic data for the children acquiring Arabic, so that they are liable to have acquired this construction as part of their native competence in Arabic - unlike Li acquirers of Arabic in other regions whose primary linguistic data did not contain a stage II negative construction.

At this stage we have a fully-fledged contact-induced change in the grammar of the Li variety of Arabic spoken by younger members of the 
increasingly bilingual Coptic community. From this point on, given the right sociolinguistic circumstances, the potential is there for the stage II negative construction to diffuse rapidly among mutually intelligible Arabic varieties. These circumstances are presumably that speakers of different varieties come into contact and that there should be a sociolinguistic incentive for speakers of the recipient variety to adopt at least some features of the source variety. Since, before long, the numbers of Arabic speakers from the Coptic community will have greatly outnumbered the Arabs in Egypt, it is not surprising that the Coptic-influenced variety should have rapidly become the norm within Egypt as a whole. (Recall that there is a sharp divide in the Arabicspeaking world between the standard written language, which is highly conservative, and the spoken varieties, concerning which there tends to be little or no prescriptivism.) From there, as mentioned in the previous section, the diffusion westwards of stage II negation is also expected, thanks to Cairo's influential position in North Africa as the seat of the Fatimid Empire and successive waves of migration from Arabia and the Levant via Egypt into western North Africa.

Thus we have the basis of a genuinely explanatory account of how contact in Egypt between Coptic, with a bipartite negative construction featuring a predominately clause-late second element, and Arabic, with its originally preverbal construction, resulted in the spread of a new Arabic bipartite construction, with a verb-adjacent second element, across the whole of coastal North Africa.

\section{Conclusion}

Taking the case of JC in Coptic and Arabic as its point of departure, this article has attempted to show how a prima facie case for contact-induced syntactic change can be evaluated, and if found to be likely, can be modelled in an explicit fashion. That is, an approach to language contact grounded, as here, in the psycholinguistic processes that lead to change in primary linguistic data, and then in grammars, can form the basis of an explanatory account of how contact leads to observed syntactic changes. From this perspective, the a priori preference for internal accounts of a given change appears no longer to be justified, particularly when such accounts cannot explain why factors which were sufficient to trigger a change in one (variety of a) language are insufficient in another. Instead it seems preferable that any given change should be evaluated on its own individual merits, and, where possible, it should be given an equally explicit account in terms of changes to the mental grammars of individual speakers, whether contact is thought to be involved or not. 
APPENDIX

\section{Abbreviations used in example glosses}

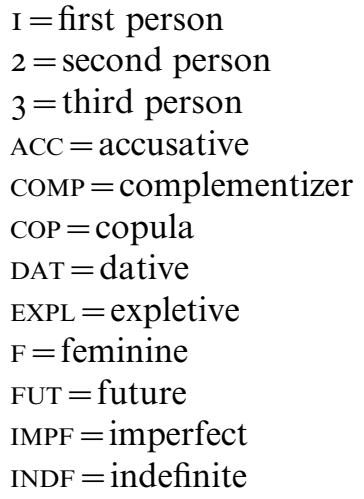

$$
\begin{aligned}
& \text { JUSS }=\text { jussive } \\
& \mathrm{M}=\text { masculine } \\
& \mathrm{NEG}=\text { negative/negation } \\
& \mathrm{NOM}=\text { nominative } \\
& \mathrm{PL}=\text { plural } \\
& \mathrm{PRF}=\text { perfect } \\
& \mathrm{PRT}=\text { particle } \\
& \mathrm{REL}=\text { relative } \\
& \mathrm{SG}=\text { singular } \\
& \mathrm{Q}=\text { question particle } \\
& \text { TEMP = past temporal }
\end{aligned}
$$

\section{Abbreviations of works cited}

I John $=$ The First Epistle of John. In George Horner (ed). I9II. The Coptic version of the New Testament in the Southern dialect: Otherwise called Sahidic and Thebaic. Oxford: The Clarendon Press.

$2 \mathrm{MAB}=$ Basil of Caesarea's Second Homily on St Michael Archangel. In

Leo Depuydt (ed). I99I. Homiletica from the Pierpont Morgan Library:

Seven Coptic homilies attributed to Basil the Great, John Chrysostom, and

Euodius of Rome. Leuven: Peeters.

BCJ = John Chrysostom's Encomium on the Bodiless Creatures. In Depuydt (I99I).

$\mathrm{C}=$ The Martyrdom of St Coluthus. In Eve Reymond \& John Barns (eds).

I973. Four martyrdoms from the Pierpont Morgan Coptic codices. Oxford:

Clarendon Press.

Gal = The Epistle of Paul to the Galatians. In Horner (I9II).

M.B = Basil of Caesarea's Encomium on St Mercurius. In Depuydt (I99I).

MA.B = Basil of Caesarea's First Homily on St Michael Archangel. In Depuydt (I99I).

MA.J = John Chrysostom's Homily on St Michael Archangel. In Depuydt (I99I).

PT $=$ Paese and Thecla. In Reymond \& Barnes (I973).

Qur'ān=Ali, Ahmed (ed). I988. Al-Qur'ān. Princeton, NJ: Princeton University Press.

RA.J = John Chrysostom's Homily on the Resurrection and the Apostles.

In Depuydt (I99I).

$\mathrm{SB}=$ Shenoufe and his Brethren. In Reymond \& Barnes (I973). 


\section{REFERENCES}

Abun-Nasr, Jamil. 1987. A history of the Maghrib. Cambridge: Cambridge University Press.

Basset, André. 1952. La langue berbère. London: Oxford University Press.

Bernini, Giuliano \& Paolo Ramat. 1996. Negative sentences in the languages of Europe: A typological approach. Berlin: Mouton de Gruyter.

Borg, Alexander. 2004. A glossary of Cypriot Maronite Arabic (Arabic-English). Leiden: Brill.

Borsley, Robert D., Maggie Tallerman \& David Willis. 2007. The syntax of Welsh. Cambridge: Cambridge University Press.

Brugnatelli, Vermondo. 1986. La negazione discontinua in berbero e in arabo-magrebino. In Giuliano Bernini \& Vermondo Brugnatelli (eds.), Atti della 4a giornata di studi camito-semitici ed indoeuropei, 53-62. Milan: Unicopli.

Brustad, Kristen. 2000. The syntax of spoken Arabic: A comparative study of Moroccan, Egyptian, Syrian and Kuwaiti dialects. Washington, DC: Georgetown University Press.

Burridge, Kate. 1993. Syntactic change in Germanic: Aspects of language change in Germanic, with particular reference to Middle Dutch. Amsterdam: John Benjamins.

Cassar, Carmel. 2000. A concise history of Malta. Msida: Mireva.

Caubet, Dominique. 2000-I. Questionnaire de dialectologie du Maghreb (d'après les travaux de W. Marçais, M. Cohen, G. S. Colin, J. Cantineau, D. Cohen, Ph. Marçais, S. Levy, etc.). Estudios de dialectologia norteafricana y andalusi 5, 73-92.

Chaker, Salem. I996. Remarques préliminaires sur la négation en berbère. In Chaker \& Caubet (eds.), II7-I34.

Chaker, Salem \& Dominique Caubet (eds.). 1996. La négation en berbère et en arabe maghrébin. Paris: L'Harmattan.

Coetsem, Frans van. 1988. Loan phonology and the two transfer types in language contact. Dordrecht: Foris.

Coetsem, Frans van. 2000. A general and unified theory of the transmission process in language contact. Heidelberg: Carl Winter.

Corriente, Federico. 1977. A grammatical sketch of the Spanish Arabic dialect bundle. Madrid: Instituto Hispano-Arabe de Cultura.

Cowell, Mark. 1964. A reference grammar of Syrian Arabic. Washington, DC: Georgetown University Press.

Dahl, Östen. I979. Typology of sentence negation. Linguistics 17, 79-I06.

Detges, Ulrich \& Richard Waltereit. 2002. Grammaticalization vs. reanalysis: A semanticpragmatic account of functional change in grammar. Zeitschrift für Sprachwissenschaft 2I.2, I5I-I95.

Döpke, Susanne. I998. Competing language structures: The acquisition of verb placement by bilingual German-English children. Journal of Child Language 25, 558-584.

Eades, Diana. 1996. Aboriginal English. In Stephen Wurm, Peter Mählhäusler \& Darrell T. Tryon (eds.), Atlas of languages of intercultural communication in the Pacific, Asia and the Americas, vol. 2, I33-I4I. Berlin: Mouton de Gruyter.

Elhalimi, Brahim. 1996. La négation dans le parler arabe de Mazouna (Ouest Algérien). In Chaker \& Caubet (eds.), I35-I62.

Eythórsson, Thórhallur. 2002. Negation in C: The syntax of negated verbs in Old Norse. Nordic Journal of Linguistics 25, 190-224.

Faber, Alice. 199I. The diachronic relationship between negative and interrogative markers in Semitic. In Alan S. Kaye (ed.), Semitic studies in honor of Wolf Leslau, vol. I, 4II-429. Wiesbaden: Otto Harrassowitz.

Gardiner, Alan. 1904. The word iwn3. Zeitschrift für Ägyptische Sprache und Altertumskunde 4I, I30-I35.

Gelderen, Elly van. 2008. The negative cycle. Linguistic Typology I2.2, I95-243.

Guichard, Pierre. 2000. Al-Andalus: 7II-I492. Paris: Hachette Littératures.

Jäger, Agnes. 2008. History of German negation (Linguistics Today I88). Amsterdam: John Benjamins.

Jespersen, Otto. 1917. Negation in English and other languages. Copenhagen: Høst.

Johnstone, Thomas. 1977. Harsüsi lexicon and English-Harsūsi word list. London: Oxford University Press.

Johnstone, Thomas. 1981. Jibbāli lexicon. London: Oxford University Press. 
Jong, Rudolf E. de. 2000. A grammar of the Bedouin dialects of the Northern Sinai littoral. Leiden: Brill.

Kickasola, Joseph. 1975. Sahidic Coptic (N) ... AN negation patterns: A morpho-syntactic description of sentences and adjuncts. Ph.D. dissertation, Brandeis University.

Lambdin, Thomas O. 1982. Introduction to Sahidic Coptic. Macon, GA: Mercer University Press.

Lass, Roger. 1997. Historical linguistics and language change. Cambridge: Cambridge University Press.

Lefebvre, Claire. 200I. Relexification in creole genesis and its effects on the development of the creole. In Norval Smith \& Tonjes Venestra (eds.), Creolization and contact, 9-42. Amsterdam: John Benjamins.

Loprieno, Antonio. 1995. Ancient Egyptian: A linguistic introduction. Cambridge: Cambridge University Press.

Lucas, Christopher. 2007. Jespersen's Cycle in Arabic and Berber. Transactions of the Philological Society 105.3, 398-43I.

Lucas, Christopher. 2009. Contact-induced grammatical change: Towards an explicit account. Ms., University of Cambridge.

Mad'aj, 'Abd al-Muhsin. 1988. The Yemen in early Islam 9-233/630-847: A political history. London: Ithaca Press.

Mailhammer, Robert. 2007. The Germanic strong verbs: Foundations and development of a new system. Berlin: Mouton de Gruyter.

Meillet, Antoine. 1912. L'évolution des formes grammaticales. Scientia 12, 384-400. [Reprinted (1948) in Meillet, Linguistique historique et linguistique générale, I30-I48. Paris: Honoré Champion.]

Meisel, Jürgen M. 1997. The acquisition of the syntax of negation in French and German: Contrasting first and second language development. Second Language Research 13.3, 227-263.

Meisel, Jürgen M. 200I. The simultaneous acquisition of two first languages: Early differentiation and subsequent development of grammars. In Jasone Cenoz \& Fred Genesee (eds.), Trends in bilingual acquisition, II-4I. Amsterdam: John Benjamins.

Meisel, Jürgen M. 2008. A quest for (transmission) failure: On child bilingualism as the locus of diachronic syntactic change. Presented at Transmission and Diffusion, Radboud Universiteit, Nijmegen.

Meltzer, Edmund. 1990. The 'prehistory' of Late Egyptian $i(w) n(3)$ : A hypothesis. Göttinger Miszellen II4, 7I-79.

Obler, Lorraine. 1990. Reflexes of Classical Arabic šay'un 'thing' in the modern dialects. In James Bellamy (ed.) Studies in Near Eastern culture and history: In memory of Ernest T. AbdelMassih, I32-I52. Ann Arbor, MI: University of Michigan.

Owens, Jonathan. 1984. A short reference grammar of eastern Libyan Arabic. Wiesbaden: Otto Harrassowitz.

Owens, Jonathan. 1988. The foundations of grammar: An introduction to medieval Arabic grammatical theory. Amsterdam: John Benjamins.

Owens, Jonathan. 2003. Arabic dialect history and historical linguistic mythology. Journal of the American Oriental Society 123, 715-740.

Owens, Jonathan. 2006. A linguistic history of Arabic. Oxford: Oxford University Press.

Parry, Mair. 1997. Preverbal negation and clitic ordering, with particular reference to a group of north-west Italian dialects. Zeitschrift für Romanische Philologie II3, 244-270.

Penka, Doris. 2007. Negative indefinites. Ph.D. dissertation, Eberhard Karls Universität Tübingen.

Reintges, Chris. 2004. Coptic Egyptian (Sahidic dialect): A learner's grammar. Cologne: Rüdiger Köppe.

Rosenhouse, Judith. I984. Towards a classification of Bedouin dialects in Israel. Bulletin of the School of Oriental and African Studies 47, 508-522.

Rowlett, Paul. 1998. Sentential negation in French. Oxford: Oxford University Press.

Schwegler, Armin. 1988. Word-order changes in predicate negation strategies in Romance languages. Diachronica 5.I/2, 2I-58.

Simeone-Senelle, Marie-Claude. 1997. The modern South Arabian languages. In Robert Hetzron (ed.), The Semitic languages, 378-423. London: Routledge. 
Solihin, Sohirin. 1991. Copts and Muslims in Egypt: A study on harmony and hostility. Leicester: The Islamic Foundation.

Stauble, Anne-Marie. I984. A comparison of a Spanish-English and a Japanese-English second language continuum: Negation and verb morphology. In Roger Andersen (ed.), Second languages: A cross-linguistic perspective, 323-353. Rowley, MA: Newbury House.

Taha, Abdulwahid. 1989. The Muslim conquest and settlement of North Africa and Spain. London: Routledge.

Tieken-Boon van Ostade, Ingrid, Tottie Gunnel \& Wim van der Wurff (eds.). 1998. Negation in the history of English. Berlin: Mouton de Gruyter.

Tsiapera, Mária. 1969. A descriptive analysis of Cypriot Maronite Arabic. The Hague: Mouton.

Turner, Lorenzo. 2002. Africanisms in the Gullah dialect. Columbia, SC: University of South Carolina Press.

Verhaar, John. 1995. Towards a reference grammar of Tok Pisin: An experiment in corpus linguistics. Honolulu, HI: University of Hawai' $i$ Press.

Watson, Janet. 1993. A syntax of Șan'āni Arabic. Wiesbaden: Otto Harrassowitz.

Watson, Janet. 2002. The phonology and morphology of Arabic. Oxford: Oxford University Press.

Watterson, Barbara. 1988. Coptic Egypt. Edinburgh: Scottish Academic Press.

Willis, David. 2006. Negation in Middle Welsh. Studia Celtica 40.I, 63-88.

Willis, David. To appear. A Minimalist approach to Jespersen's Cycle in Welsh. In Stephen R. Anderson \& Dianne Jonas (eds.), Syntactic variation and change. Oxford: Oxford University Press.

Winand, Jean. 1997. La négation bn... iwn3 en Néo-Égyptian. Lingua Aegyptia 5, 223-236.

Winford, Donald. 2005. Contact-induced changes: Classification and processes. Diachronica $22.2,373-427$.

Woidich, Manfred. 1968. Negation und negative Sätze im Ägyptisch-Arabischen. Ph.D. dissertation, Ludwig-Maximilians-Universität zu München.

Woidich, Manfred. 2006. Das Kairenisch-Arabische: Eine Grammatik. Wiesbaden: Otto Harrassowitz.

Authors'address: Department of Linguistics, Faculty of Modern and Medieval Languages, University of Cambridge, Sidgwick Avenue, Cambridge CB3 9DA, UK

cbl23@cam.ac.uk

ejfl2@cam.ac.uk 